\title{
Kemampuan Pembentukan Kalus 8 Varietas Tebu (Saccharum offisinarum) Pada Media MS Modifikasi
}

\author{
Callus Formation Ability of 8 Sugarcane (Saccharum offisinarum) Varieties on Modified \\ MS Media
}

\author{
Tika Rahma Yunita, Muhammad Rizal*, Dwi Isyana Achmad, Muhammad Ali \\ Program Studi D4 Budidaya Tanaman Perkebunan, Jurusan Teknologi Pertanian, Politeknik \\ Negeri Pontianak, Indonesia. \\ ${ }^{*}$ Corresponding Author: mr_izal@polnep.ac.id
}

\begin{abstract}
Abstrak
Tebu merupakan salah satu komoditi ekspor Indonesia yang penting, sehingga banyak ditanam di Indonesia. Sehingga kegiatan pengadaan bibit tebu perlu untuk dilakukan. Penyediaan bibit tebu dapat dilakukan melalui teknik kultur jaringan untuk mendapatkan bibit dalam jumlah besar dan bebas dari hama dan penyakit. Langkah awal untuk menghasilkan bibit tebu adalah dengan menginduksi kalus. Tujuan dari penelitian ini adalah untuk menginduksi kalus dari delapan varietas tebu yang digunakan, serta untuk mengetahui kemampuan pembentukan kalus dari delapan varietas tebu. Bahan yang digunakan adalah delapan varietas tebu 383, 316, R 236, TC 15, TC 09, X 4, X 8, dan X 157, dan media MS yang telah dimodifikasi untuk pertumbuhan kalus. Pengamatan dilakukan pada persen terbentuknya kalus. Terdapat dua varietas yang dapat membentuk kalus yatu $X 157$, dan $X 8$ dengan persen terbentuknya kalus secara berurutan adalah $0,7 \%$ dan $0,5 \%$.
\end{abstract}

Kata kunci: kalus, 8 varietas tebu, media MS

\begin{abstract}
Sugarcane is one of Indonesia's important export commodities, so it is widely grown in Indonesia. So that sugarcane seed procurement activities need to be carried out. Supply of sugarcane seeds can be done through tissue culture techniques to obtain seeds in large quantities and free from pests and diseases. The first step to produce sugarcane seeds is to induce callus. The purpose of this study was to induce callus from eight sugarcane varieties used, and to determine the callus formation ability of eight sugarcane varieties. The materials used were eight varieties of sugarcane 383, 316, R 236, TC 15, TC 09, X 4, X 8, and X 157, and modified MS medium for callus growth. Observations were made on the percentage of callus formation. There are two varieties that can form callus, namely $X 157$ and $X 8$ with the percentage of callus formation respectively $0.7 \%$ and $0.5 \%$.
\end{abstract}

Keywords: callus, 8 varieties of sugarcane, MS media

\section{PENDAHULUAN}

Tebu (Saccharum officinarum L.) merupakan salah satu komoditas strategis, karena digunakan sebagai bahan baku berbagai industri seperti gula (gula Kristal putih/ GKP), bioetanol, asam amino, asam organik dan bahan pangan (Balitbangtan, 2015). Data Ditjenbun tahun 2021 menunjukkan bahwa produktivitas GKP mengalami penurunan dari tahun 2015, dengan rata-rata $0,53 \%$ pertahun. Penuruan ini disebabakan oleh beberapa factor, salah satunya adlaah penyediaan bibit unggul dan sehat.
Program bibit unggul dapat dicapai dengan cara konvensional maupun non konvensional. Secara non konvensional bibit unggul tebu dapat dicapai dengan teknik kultur jaringan. Keunggulan dari teknik budidaya in vitro untuk pengadaan bibit tebu yang unggul adalah faktor penggandaannya yang tinggi sehingga varietas unggul cepat diperbanyak, bibit lebih terjamin kesehatannya, membutuhkan ruang yang relatif kecil, bahan tanam dan pohon induk sedikit, dan eksplan dapat diproduksi secara cepat dan banyak (Mariska \& Rahayu, 2011). Tahapan pertama yang dilakukan untuk mendapatkan bibit unggul adalah 
dengan pembentukan kalus. kalus merupakan massa sel yang tidak terorganisir yang terbentuk pada jaringan luka. Sel kalus terbentuk dari sel meristem atau pun sel yang telah mengalami diferensiasi, seperti sel parenchyma pada daun. (Rusdianto, dan Indrianto. 2012). Tujuan dari penelitian ini adalah untuk menginduksi kalus dari delapan varietas tebu yang digunakan, serta untuk mengetahui kemampuan pembentukan kalus dari delapan varietas tebu.

\section{METODE PENELITIAN}

Penelitian ini dilaksanakan di Laboratorium IImu Tanaman Perekebunan II Jurusan Teknologi Pertanian, dari bulan Mei hingga bulan Agustus 2021.

Eksplan yang digunakan adalah jaringan meristem tebu (tunas muda). Sterilisasi eksplan tunas muda menggunakan metode modifikasi dari Juwanda, Khotimah, dan Amin (2016), yaitu dengan mencuci bersih batang tebu dengan air mengalir, kemudian direndam dengan larutan detergen selama 15 menit. Batang tebu yang telah bersih kemudian direndam kembali dengan fungisida dan bakterisida masing-masing 60 menit. Eksplan yang permukaannya telah steril selanjutnya dibawa ke dalam Laminair Air Flow dan direndam menggunakan Chlorox dengan kosentrasi $30 \%$ selama 20 menit lalu dibilas dengan aquadest steril, dikering anginkan, dan dikupas daunnya hingga mendapatkan tunas muda. Tunas kemudian dipotong dengan ukuran $0,5 \mathrm{~cm} \times 0.5 \mathrm{~cm}$ dan direndam kembali dengan Chlorox 10\% selama 10 menit dan Chlorox $5 \%$ selama 5 menit diselingi dengan pembilasan menggunakan aquadest steril. Media kultur yang digunakan adalah media Murasige dan Skoog (MS) yang diperkaya dengan penambahan 2,5 ppm 2,4dichlorophenoxyacetic acid (2,4-D) dan 2 ppm BA (6-benzyladenine) sesuai peruntukan (kalus/plantlet).

Varietas tebu yang digunakan merupakan varietas unggul yang didapatkan dari kerjasama dengan pihak industri yaitu anak perusahaan PT. Kalindoyang yang saat ini sedang mengembangkan varietas unggul tebu di Kalimantan Barat. Delapan varietas tebu yang digunakan adalah varietas 383, 316, R 236, TC 15, TC 09, X 4, X 8, dan X 157.

Pengamatan dilakukan dengan menghitung persentase terbentuknya kalus dari delapan varietas tebu yang digunakan.

\section{HASIL DAN PEMBAHASAN}

Delapan varietas tebu yang ditanam pada media MS dengan penambahan 2,5 ppm 2,4-dichlorophenoxyacetic acid (2,4 D) dan 2 ppm BA (6-benzyladenine) sebagian besar terjadi browning dan kontam, hanya beberapa eksplan saja yang menunjukkan pertumbuhan kalus, yaitu varietas X 157 , dan $X 8$, dengan presentase pembentukan kalus secara berurutan adalah: $0,7 \%$ dan $0,5 \%$. Persentase pembentukan kalus menunjukkan tingkat esponsive eksplan pada perlakuan yang diuji (Rasud \& Bustaman, 2020).

Modifikasi media MS untuk induksi kalus tebu telah banyak dilaporkan dan bervariasi, seperti hasil penelitian Arjun dan Rao (2015) induksi kalus tebu menggunakan 2,4-D 3,5 mg/l + 0,3 mg/L BAP bisa meningkatkan pebentukan kalus tebu, tetapi penambahan air kelapa dan 0,5 mg/l BAP menghasilkan pertumbuhan kalus yang maksimum. Modifikasi media MS dengan Konsentrai 2,5 mg/L 2,4-D menunjukkan nilai pembentukan kalus tertinggi dibandingkan dengan konsentrasi $1 \mathrm{mg} / \mathrm{L}$ dan $5 \mathrm{mg} / \mathrm{L}$ (Inderiati dkk, 2021).

Keberhasilan regenerasi tanaman tebu secara in vitro tergantung dari genotype tanaman, sumber eksplan, dan formulasi media (Behera dan Sahoo, 2009). Respon varietas tebu yang berbeda-beda untuk inisiasi pembentukan kalus pada beberapa formulasi media, diduga berkaitan dengan kemampuan sel dan jaringan setiap varietas untuk merespon ZPT yang diberikan. Hal ini sering disebut sebagai genotype dependent (Gill et al., 2004; Abu et al., 2014 cit Suherti et al., 2015). 

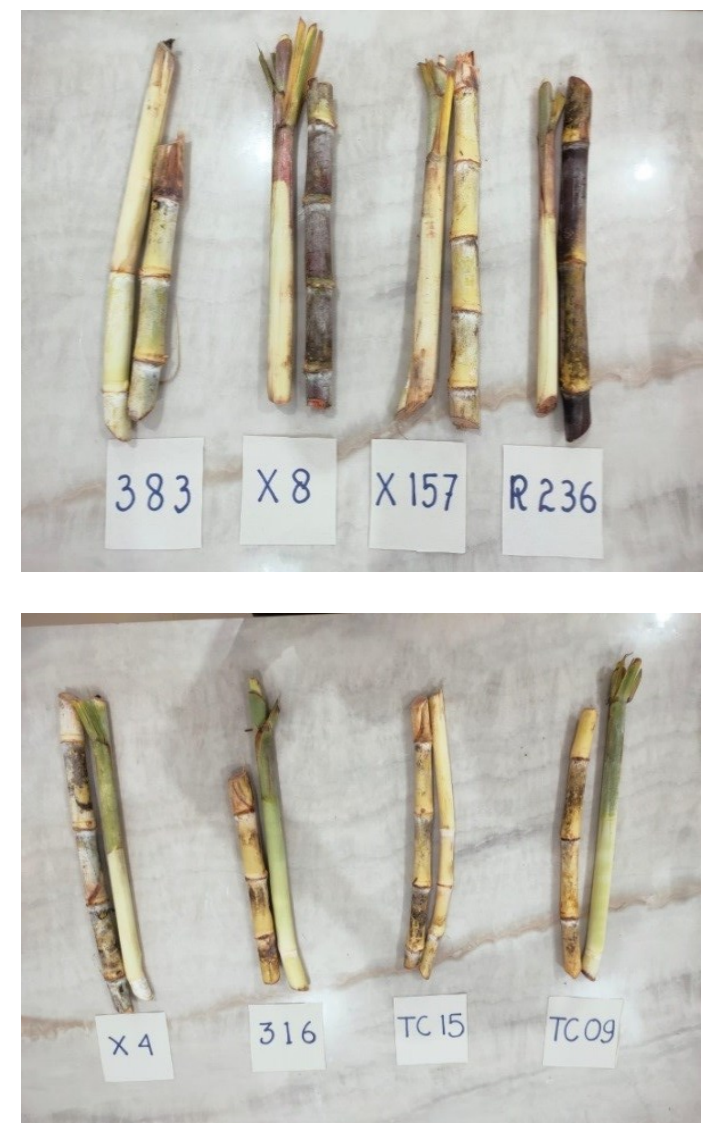

Gambar 1. Delapan varietas tebu yang diinduksi kalus.

Kalus merupakan massa sel yang tidak terorganisir yang terbentuk pada jaringan luka (Rusdianto \& Indrianto, 2012). Tanggapan luka tersebut ditandai dengan pembelahan sel yang semakin meningkat hingga menjadi kumpulan massa sel yang belum terdeferensiasi (Liang, 2007). Kalus mulai tumbuh pada lima hari setelah kultur (gambar 3), sedangkan kontaminasi sudah mulai terlihat pada pengamatan hari ke-7 setelah kultur (gambar 2).

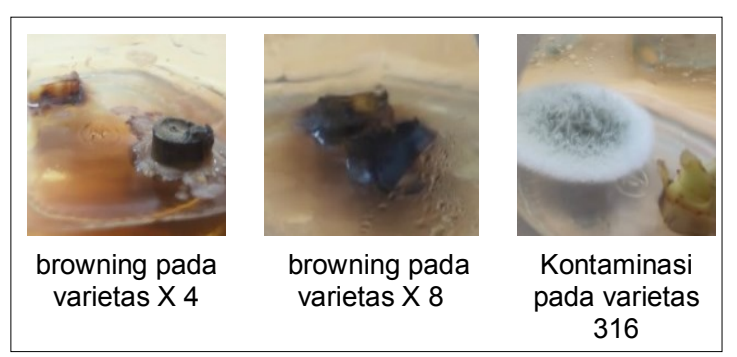

Gambar 2. Eksplan yang browning dan kontaminasi

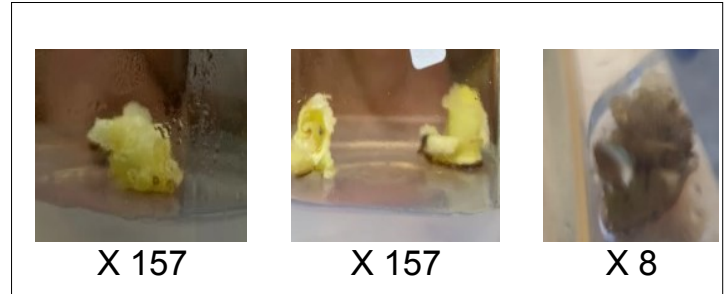

Gambar 3. Pembentukan kalus varietas $X$ 157 dan X 8 pada

Permasalahan dalam kultur in vitro adalah adanya kontaminasi oleh bakteri dan jamur serta pencoklatan (browning). Kontaminasi merupakan suatu kejadian tumbuhnya kontaminan berupa jamur bakteri atau virus pada eksplan maupun media tanam sedangkan pencoklatan merupakan kejadian berubahnya warna eksplan menjadi coklat (brown) atau hitam karena sel yang terdegradasi atau rusak. Pencoklatan maupun kontaminasi sering kali menghambat pertumbuhan dan perkembangan eksplan dan mengakibatkan kematian pada jaringan (Purba, 2017).

Penghambatan pertumbuhan biasanya sangat kuat pada beberapa spesies yang umumnya mengandung senyawa tannin atau hidroksi fenol dengan konsentrasi tinggi. Fenol mempunyai fungsi alami penting dalam mengatur oksidasi IAA. Toksisitas fenol kemungkinan disebabkan oleh ikatan reversible antara hydrogen dan protein. Penghambatan pertumbuhan yang tidak dapat diperbaiki terjadi ketika fenol teroksidasi menjadi senyawa aktif quinon yang tinggi sehingga memolimerase dan/atau mengoksidasi protein senyawa melanat yang makin meningkat (Hutami 2008).

\section{KESIMPULAN}

Kemampuan induksi kalus dari delapan varietas tebu berbeda, sebagian besar dari delapan varietas tersebut menghasilkan browning saat dikulturkan. Hanya varietas $X$ $157(0,7 \%)$ dan X8 (0,5\%) yang dapat membentuk kalus pada media MS dengan penambahan 2,5 ppm 2,4D dan 2 ppm BA.

\section{DAFTAR PUSTAKA}

Arjun and S. Rao. 2015. Callus Induction and Organonesis in Sugarcane 
(Saccharum oinarum L.) Var 93v297. International Letters of Natural Science Vol. 48: 14-22.

Badan Penelitian dan Pengembangan Pertanian (Balitbang). 2015. Peningkatan Produktivitas dan Rendemen Tebu Melalu Rekayasa Fisiologi Pertunasan. Jakarta

Behera, K.K. and S. Sahoo. 2009. Rapid in vitro micropropagation of sugarcane (Saccharum officinarum L. cv-Nayana) through callus culture. Nature Science, 7(4): 1-10.

Direktorat Jendral Perkebunan. 2021. Statistik Perkebunan Unggulan Nasional 20192021. www.ditjenbun.pertanian.go.id. Diakses tanggal 5 Oktober 2021.

Hutami S. 2008. Ulasan Masalah Pencoklatan pada Kultur Jaringan. Jurnal Agribiogen, Vol: 4(2): 83-88.

Inderiati S., Yanti, E.R. Mentari. 2021. Induksi Kalus Morfogenik dan Regenerasi Tanaman Tebu (Saccharum officinarum L.) secara In Vitro. Journal of Applied Agricultural Sciences Vol. 5(1): 61-67

Juwanda, M., K. Khotimah dan M. Amin. 2016. Peningkatan Ketahan Bawang Merah Terhadap Penyakit Layu Fusarium Melalui Induksi Ketahanan dengan Asam Salisilat Secara Invitro. Agrin 20(1): 15-28.

Liang, O.P. 2007. Micropropagation and Callus Culture of Phyllanthus niruri L., Phyllanthus urinaria L., and Phyllanthus myrtifolius (Euphorbiaceae) with The Establishment of Cell Suspension Culture of Phyllanthus niruri L.. University Sains Malaysia. Thesis

Mariska, I., dan S. Rahayu. 2011. Pengadaan Bibit Tebu melalui Kultur Jaringan. Jurnal Libang Pertanian Edisi 6-12 Juli 2012 No.3413 Tahun XLI.

Pratiwi B N., Liliek S., Anton M \& Ari K. 2013. Uji Pengendalian Penyakit Pokahbung (Fusarium moniliformae) Pada Tanaman Tebu (Saccharum officinarum) Menggunakan Trichoderma sp. indigenous Secara In Vitro dan In Vivo. J.HPT 1(3): 119-129 ISSN : 2338 $-4336$.

Purba, R. V. 2017. Induksi kalus eksplan daun tanaman anggur (Vitis vinivera L.) dengan aplikasi 2,4-D secara in-vitro.
E-Jurnal Agroekoteknologi Tropika 6: 2301-6515.

Rasud, Y., dan Bustaman. 2020. Induksi Kalus secara In Vitro dari Daun Cengkeh (Syizigium aromaticum L.) dalam Media dengan Berbagai Konsentrasi Auksin. Jurnal IImu Pertanian Indonesia (JIPI), Januari 2020 Vol. 25

Rusdianto, dan Indrianto. 2012. Induksi Kalus Embriogenik pada Wortel (Daucus carota) dengan Menggunakan 2,4-D. Jurnal Bionature. 13(2): $136 \square 140$.

Suherti S., N. Khumaida, G.A. Wattimena, M. Syukur, A. Husni, E. Hadipoentyanti, dan R.R.S. Hartati. 2015. Induksi Kalus dan Regenerasi Dua Varietas Tebu (Saccharum officinarum L.) Secara In Vitro. Jurnal Littri 21(2): 77-88. 